\title{
Venous thromboembolism after oral and maxillofacial oncologic surgery: Report and analysis of 14 cases in Chinese population
}

\author{
Yang Wang ${ }^{1}$, Jiannan Liu ${ }^{1}$, Xuelai Yin ${ }^{1}$, Jingzhou Hu ${ }^{2}$, Evagelos Kalfarentzos ${ }^{3}$, Chenping Zhang ${ }^{4}$, Liqun \\ $\mathrm{Xu}{ }^{2}$
}

${ }^{1}$ DDS, PHD, Resident doctor. Department of Oral maxillofacial-Head and Neck Oncology, Shanghai Ninth People's Hospital, College of Stomatology, Shanghai Jiao Tong University School of Medicine, Shanghai Key Laboratory of Stomatology and Shanghai Research Institute of Stomatology, Shanghai, China

${ }^{2}$ DDS, PHD, Professor. Department of Oral maxillofacial-Head and Neck Oncology, Shanghai Ninth People's Hospital, College of Stomatology, Shanghai Jiao Tong University School of Medicine, Shanghai Key Laboratory of Stomatology and Shanghai Research Institute of Stomatology, Shanghai, China

${ }^{3}$ MD, DDS, PHD, Resident doctor. Department of oral \& maxillofacial surgery, University of Athens dental school

${ }^{4}$ DDS, PHD, Professor. Department Head, Department of Oral maxillofacial-Head and Neck Oncology, Shanghai Ninth People's Hospital, College of Stomatology, Shanghai Jiao Tong University School of Medicine, Shanghai Key Laboratory of Stomatology and Shanghai Research Institute of Stomatology, Shanghai, China

Correspondence:

Department of Oral maxillofacial-Head and Neck Oncology

Shanghai Ninth People's Hospital

College of Stomatology

Shanghai Jiao Tong University School of Medicine

Zhi-zao-ju Road No 639, Shanghai

China 200011

maxillaxuliqun@163.com

Received: $27 / 04 / 2016$

Accepted: 26/10/2016

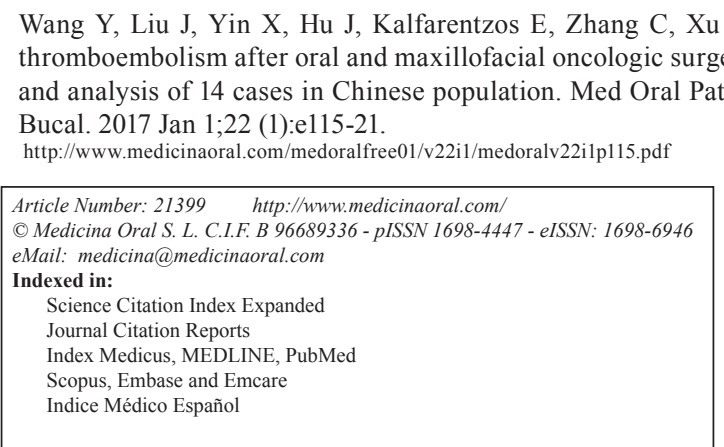

\begin{abstract}
Background: Venous thromboembolism (VTE) including deep vein thrombosis (DVT) and pulmonary embolism (PE) is a leading cause of death in cancer patients. The aim of this study was to explore the potential risk factor of VTE in oral and maxillofacial oncological surgery.

Material and Methods: The data of patients who received operation in our institution were gathered in this retrospective study. A diagnosis of VTE was screened and confirmed by computer tomography angiography (CTA) of pulmonary artery or ultrasonography examination of lower extremity. Medical history and all perioperative details were analyzed.

Results: 14 patients were diagnosed as VTE, including 6 cases of PE, 7 cases of DVT, 1case of DVT and PE. The mean age of these patients was 62.07 years. Reconstruction was performed in 12 patients of these cases, most of which were diagnosed as malignance. Mean length of surgery was 8.74 hours, and lower extremity deep venous cannula (DVC) was performed in all these patients.

Conclusions: We analyzed several characters of oral and maxillofacial surgery and suggested pay attention to lower extremity DVC which had a high correlation with DVT according to our data.
\end{abstract}

Key words: Venous thromboembolism, pulmonary embolism, deep vein thrombosis, oral and maxillofacial surgery. 


\section{Introduction}

Thromboembolism is a well recognized complication of malignant disease and it is known that malignant disease itself can predispose to a hyper-coagulable state secondary to polycythemia vera. And cancer patients have a higher incidence of venous thromboembolism (VTE), including pulmonary embolism (PE) and deep venous thrombosis (DVT), compared to the general population (1). Therefore, cancer patients undergoing major surgery are considered particularly high risk for VTE.

The incidence of thromboembolic disease in general population is relatively low, about $0.1 \%-0.3 \%$ per year while among cancer patients, the occurrence of VTE is 4-7 times higher, depending on the type and the stage of cancer (2). Several retrospective studies revealed the incidence of VTE in head and neck cancer patients between $0.1 \%$ and $2 \%(3-7)$. The largest review was published by Moreano (3) and reviewed the records of 12,805 otolaryngologic patients with an overall incidence of DVT and pulmonary embolism of $0.3 \%$ and $0.2 \%$, respectively. Patients with head and neck cancer usually undergo comprehensive resection and reconstruction and frequently exhibit many of the major risk factors for DVT and PE. These risk factors include advanced age, postoperative immobility, prolonged surgical procedure and et al. In accord with current criteria, most patients with head and neck cancer who have surgery are presumed to be high risk for developing VTE, especially for patients undergoing simultaneous recon- struction. The purpose of this study was to identify potential risk factors of VTE in oral and maxillofacial oncological surgery.

\section{Material and Methods}

This study was approved by the Ethics Committee of Shanghai Ninth People's Hospital. All the patients with tumor, including benign or malignant tumors, discharged from January 2011 to December 2015, that received operation in Oral Maxillofacial-Head Neck Department, Shanghai 9th Hospital were selected for study. All the detail of medical history was recorded, including gender, age, smoke/alcohol history, comorbidities, previous surgeries, prior chemotherapy or radiation therapy, prior VTE history, histology, preoperative D-dimer and et al. The characters of the surgery procedure were recorded including operative time, blood loss, blood transfusion, lower extremity DVC, simultaneous reconstruction and et al. Perioperative findings were summarized including abnormal symptoms and the time point as discovered, diagnosis method, treatment and other complications (Tables 1-3).

Finally, a total of 9724 patients were included in this study and 14 patients were diagnosed as VTE, including 6 cases of PE, 7 cases of DVT, 1case of DVT and PE. The overall incidence of VTE was about $0.14 \%$. The diagnoses were confirmed by computer tomography angiography (CTA) of pulmonary artery or ultrasonography examination of lower extremity.

Table 1. Preoperative medical record detail.

\begin{tabular}{|c|c|c|c|c|c|c|c|c|c|c|}
\hline Patient & VTE & Gender & Age & Smoke & Alcohol & Comorbidities & Medication & $\begin{array}{c}\text { Previous } \\
\text { surgery }\end{array}$ & $\begin{array}{l}\text { Pathological } \\
\text { Diagnosis }\end{array}$ & D-dimer \\
\hline 1 & DVT & M & 48 & + & + & - & - & + & SCC & 0.4 \\
\hline 2 & DVT & M & 73 & - & + & $\begin{array}{c}\text { Pituitary } \\
\text { adenoma } \\
\text { Hypopituitarism }\end{array}$ & $\begin{array}{l}\text { Prednisone, } \\
\text { Levothyroxine } \\
\text { Sodium, } \\
\text { VitaminD }\end{array}$ & $\stackrel{+}{+} \stackrel{+}{(\mathrm{CR})}$ & $\begin{array}{c}\mathrm{SCC} \\
\text { (recurrence) }\end{array}$ & $\begin{array}{l}6.45 / \\
4.31\end{array}$ \\
\hline 3 & DVT & F & 58 & - & - & Hypertension & $\begin{array}{l}\text { Indapamide, } \\
\text { Amlodipine }\end{array}$ & + & $\mathrm{SCC}$ & / \\
\hline 4 & DVT & M & 61 & + & + & - & - & - & $\mathrm{SCC}$ & 0.58 \\
\hline 5 & DVT & $\mathrm{F}$ & 53 & - & - & - & - & - & $\mathrm{SCC}$ & / \\
\hline 6 & DVT & M & 50 & - & - & - & - & $\begin{array}{l}++ \\
(\mathrm{CR}) \\
\end{array}$ & $\begin{array}{c}\text { ACC } \\
\text { (recurrence) } \\
\end{array}$ & / \\
\hline 7 & DVT & $M$ & 72 & - & - & - & - & - & $\mathrm{SCC}$ & / \\
\hline 8 & $\begin{array}{c}\text { DVT } \\
\text { PE }\end{array}$ & F & 32 & - & - & - & - & - & Ameloblastoma & \\
\hline 9 & PE & $\mathrm{F}$ & 78 & - & - & $\begin{array}{c}\text { Cerebral } \\
\text { infarction }\end{array}$ & - & $\begin{array}{c}++ \\
(\mathrm{CR}) \\
\end{array}$ & $\begin{array}{c}\mathrm{SCC} \\
\text { (recurrence) }\end{array}$ & 0.64 \\
\hline 10 & PE & M & 69 & - & - & Diabetes & - & - & MEC & 0.58 \\
\hline 11 & PE & M & 70 & - & - & Diabetes & $\begin{array}{l}\text { Metformin, } \\
\text { Diamicron }\end{array}$ & - & $\mathrm{SCC}$ & / \\
\hline 12 & $\mathrm{PE}$ & $\mathrm{F}$ & 59 & - & - & Hypertension & - & + & $\mathrm{ACC}$ & 0.29 \\
\hline 13 & PE & M & 74 & + & + & - & - & - & $\mathrm{SCC}$ & I \\
\hline 14 & PE & M & 72 & - & - & - & - & - & SCC & / \\
\hline
\end{tabular}

Abbreviations: M, male; F, female; SCC, squamous cell carcinoma; MEC, mucoepidermoid carcinoma; ACC, adenoid cystic carcinoma; CR, cancer related. 
Table 2. Medical record details of operation.

\begin{tabular}{|c|c|c|c|c|c|c|c|}
\hline \multirow{2}{*}{ Patient } & \multirow{2}{*}{ VTE } & \multicolumn{3}{|c|}{ Operative program } & \multirow{2}{*}{$\begin{array}{l}\text { Surgery } \\
\text { procedure } \\
\text { (hour) }\end{array}$} & \multirow{2}{*}{$\begin{array}{l}\text { Blood loss } \\
\quad(\mathrm{ml})\end{array}$} & \multirow{2}{*}{$\begin{array}{c}\text { Blood } \\
\text { transfusion } \\
\quad(\mathrm{ml})\end{array}$} \\
\hline & & $\begin{array}{c}\text { Flap } \\
\text { Reconstruction }\end{array}$ & $\begin{array}{c}\text { Vascular } \\
\text { Anastomosis }\end{array}$ & Tracheotomy & & & \\
\hline 1 & DVT & - & - & + & 10.75 & 300 & 400 \\
\hline 2 & DVT & PMMF & - & + & 8.5 & 800 & 1000 \\
\hline 3 & DVT & ALTF（L） & + & + & 11.83 & 1000 & 1000 \\
\hline 4 & DVT & Forearm Flap & + & - & 7 & 400 & 0 \\
\hline 5 & DVT & Forearm Flap & + & - & 9.75 & 500 & 0 \\
\hline 6 & DVT & Fibula Flap (R) & + & + & 10.75 & 1000 & 600 \\
\hline 7 & DVT & - & - & - & 4.58 & 500 & 0 \\
\hline 8 & $\begin{array}{c}\text { DVT } \\
\text { PE }\end{array}$ & DCIA（R） & + & - & 9 & 450 & 0 \\
\hline 9 & $\mathrm{PE}$ & PMMF & - & + & 8 & 800 & 400 \\
\hline 10 & PE & $\operatorname{ALTF}(\mathrm{R})$ & + & + & 10.25 & 700 & 400 \\
\hline 11 & $\mathrm{PE}$ & ALTF（R） & + & + & 7.25 & 700 & 0 \\
\hline 12 & $\mathrm{PE}$ & ALTF（L） & + & + & 9 & 650 & 0 \\
\hline 13 & $\mathrm{PE}$ & ALTF（L） & + & + & 10 & 500 & 200 \\
\hline 14 & PE & - & - & - & 5.5 & 300 & 0 \\
\hline
\end{tabular}

Abbreviations: PMMF, pectoralis major myocutaneous flap; ALTF, anterior lateral thigh flap; DCIA, deep circumflex iliac artery; L, left; R, right.

Table 3. Postoperative medical record details.

\begin{tabular}{|c|c|c|c|c|c|c|c|c|}
\hline Patient & VTE & $\begin{array}{l}\text { Postoperative } \\
\text { prophylaxis }\end{array}$ & $\begin{array}{l}\text { Caprini } \\
\text { Score }\end{array}$ & $\begin{array}{l}\text { Lower extremity } \\
\text { DVC (day) }\end{array}$ & Initial symptoms & $\begin{array}{l}\text { Time point } \\
\text { (post-op day) }\end{array}$ & $\begin{array}{l}\text { Postoperative } \\
\text { complications }\end{array}$ & Treatment \\
\hline 1 & DVT & Alprostadil & 10 & $3(\mathrm{R})$ & $\begin{array}{c}\text { Pain in lower extremity } \\
\text { DVC (R) }\end{array}$ & 13 & PI & $\begin{array}{c}\text { Inferior vena cava } \\
\text { filter Anti-infection } \\
\text { therapy }\end{array}$ \\
\hline 2 & DVT & - & 11 & $4(\mathrm{R})$ & Swelling of foot (R) & 10 & $\begin{array}{c}\text { PI } \\
\text { Pleural effusion }\end{array}$ & $\begin{array}{c}\text { Immobilization } \\
\text { LMWH } \\
\text { Anti-infection therapy }\end{array}$ \\
\hline 3 & DVT & Alprostadil & 10 & $3(\mathrm{R})$ & $\begin{array}{l}\text { Swelling and increased } \\
\text { skin temperature of } \\
\text { lower extremity }(\mathrm{L})\end{array}$ & 9 & PI & $\begin{array}{c}\text { Inferior vena cava } \\
\text { filter } \\
\text { Urokinase } \\
\text { thrombolysis } \\
\end{array}$ \\
\hline 4 & DVT & Alprostadil & 11 & $5(\mathrm{R})$ & $\begin{array}{c}\text { Pain in lower extremity } \\
\text { DVC (R) }\end{array}$ & 6 & - & $\begin{array}{l}\text { Immobilization } \\
\text { +LMWH }\end{array}$ \\
\hline 5 & DVT & Alprostadil & 10 & $0(\mathrm{~L})$ & $\begin{array}{l}\text { Swelling of lower } \\
\text { extremity (L) }\end{array}$ & 0 & - & $\begin{array}{l}\text { Immobilization } \\
\text { +LMWH }\end{array}$ \\
\hline 6 & DVT & Alprostadil & 10 & $3(\mathrm{~L})$ & $\begin{array}{l}\text { Swelling of lower } \\
\text { extremity }(\mathrm{R})\end{array}$ & 8 & PI & LMWH \\
\hline 7 & DVT & - & 9 & $1(\mathrm{R})$ & $\begin{array}{l}\text { Pain in lower extremity } \\
\text { (R) }\end{array}$ & 5 & - & $\begin{array}{l}\text { Immobilization + } \\
\text { LMWH }\end{array}$ \\
\hline 8 & $\begin{array}{l}\text { DVT } \\
\text { PE }\end{array}$ & Alprostadil & 9 & $3(\mathrm{~L})$ & $\begin{array}{l}\text { Swelling of lower } \\
\text { extremity }(\mathrm{R})\end{array}$ & 3 & - & $\begin{array}{c}\text { Urokinase } \\
\text { thrombolysis } \\
\text { Warfarin }\end{array}$ \\
\hline 9 & $\mathrm{PE}$ & Alprostadil & 12 & $3(\mathrm{R})$ & $\begin{array}{c}\text { Thoracalgia } \\
\text { Decline of SPO2 }\end{array}$ & 3 & PI & $\begin{array}{c}\text { LMWH } \\
\text { Anti-infection therapy }\end{array}$ \\
\hline 10 & $\mathrm{PE}$ & - & 11 & $/(\mathrm{L})$ & Decline of SPO2 & 5 & $\begin{array}{c}\text { PI } \\
\text { Atelectasis }\end{array}$ & $\begin{array}{c}\text { LMWH } \\
\text { Anti-infection therapy }\end{array}$ \\
\hline 11 & $\mathrm{PE}$ & - & 11 & $3(\mathrm{~L})$ & Fever + Decrease of $\mathrm{PaO} 2$ & 9 & PI & $\begin{array}{c}\text { Immobilization + } \\
\text { LMWH }\end{array}$ \\
\hline 12 & $\mathrm{PE}$ & - & 10 & $3(\mathrm{R})$ & Decline of SPO2 & 6 & $\begin{array}{c}\text { PI } \\
\text { Pleural effusion }\end{array}$ & LMWH \\
\hline 13 & $\mathrm{PE}$ & - & 11 & $6(\mathrm{R})$ & Decline of SPO2 & 3 & $\begin{array}{c}\text { PI } \\
\text { Aspiration } \\
\text { pneumonia }\end{array}$ & LMWH \\
\hline 14 & $\mathrm{PE}$ & - & 11 & $5(\mathrm{R})$ & $\begin{array}{l}\text { Chest tightness } \\
\text { Expiratory dyspnea } \\
\text { Pain in groin }\end{array}$ & 12 & PI & $\begin{array}{c}\text { Inferior vena cava } \\
\text { filter } \\
\text { Urokinase } \\
\text { thrombolysis } \\
\end{array}$ \\
\hline
\end{tabular}

Abbreviations: LMWH, low molecular weight heparin; PI, pulmonary infection; post-op, post operation; L, left; R, right. 


\section{Results}

The mean age of these patients was 62.07 years $( \pm 12.95$; range from 32 to 78). There were 9 men and 5 women. 4 patients had a smoking history and 5 patients had a history of alcohol intake. In the term of basic disease, 2 patients had a history of hypertension and 2 patients had got diabetes. 6 patients had suffered a previous surgery including 3 malignance resulted in operation, and 1 operation was lower extremity involved. One patient had received a prior chemotherapy and radiotherapy (Table 4). Reconstruction was performed in 12 patients of these cases, most of which were all diagnosed as malignance, including 1 fibula flap, 1 DCIA flap, 2 forearm

Table 4. Patient characteristics.

\begin{tabular}{|c|c|}
\hline Variable & $\begin{array}{l}\text { Patients with } \\
\text { VTE }\end{array}$ \\
\hline Mean Age \pm SD (years) & $62.07 \pm 12.95$ \\
\hline \multicolumn{2}{|l|}{ Age group } \\
\hline$<45$ & 1 \\
\hline$\geq 45$ & 13 \\
\hline \multicolumn{2}{|l|}{ Gender } \\
\hline Male & 9 \\
\hline Female & 5 \\
\hline Smoking & 4 \\
\hline Alcohol & 5 \\
\hline \multicolumn{2}{|l|}{ Basic disease } \\
\hline Hypertension & 2 \\
\hline Diabetes & 2 \\
\hline \multicolumn{2}{|l|}{ Previous surgery } \\
\hline Yes & 6 \\
\hline No & 8 \\
\hline \multicolumn{2}{|l|}{ Malignant disease } \\
\hline Yes & 13 \\
\hline SCC & 10 \\
\hline $\mathrm{ACC}$ & 2 \\
\hline MEC & 1 \\
\hline No & 1 \\
\hline \multicolumn{2}{|l|}{ Prior chemotherapy/radiotherapy } \\
\hline Yes & 1 \\
\hline No & 13 \\
\hline \multicolumn{2}{|l|}{ Preoperative D-dimer } \\
\hline$<0.5$ & 2 \\
\hline$\geq 0.5$ & 4 \\
\hline
\end{tabular}

flaps, 2 pectoris major myocutenous flaps (PMMF) and 6 anterior lateral thigh flaps (ALTF) (Table 5).

Mean length of surgery was 8.74 hours $( \pm 2.06$; range from 4.58 to 10.75 ). Mean blood loss was $628.57 \mathrm{ml}( \pm$ 222.50; range from 1000 to 300 ), and 7 patients got blood transfusion and mean amount was $592.86 \mathrm{ml}( \pm 322.01$;

Table 5. Statistical perioperative findings.

\begin{tabular}{|c|c|}
\hline Characteristics & Outcome \\
\hline Mean operation time \pm SD (hours) & $8.74 \pm 2.06$ \\
\hline \multicolumn{2}{|l|}{ Reconstruction surgery } \\
\hline Yes & 12 \\
\hline Fibula Flap & 1 \\
\hline DCIA & 1 \\
\hline Forearm Flap & 2 \\
\hline PMMF & 2 \\
\hline ALTF & 6 \\
\hline No & 2 \\
\hline Mean blood loss $(\mathrm{ml})$ & $628.57 \pm 222.50$ \\
\hline \multicolumn{2}{|l|}{ Blood transfusion } \\
\hline Yes & 7 \\
\hline Mean amount $(\mathrm{ml})$ & $592.86 \pm 322.01$ \\
\hline No & 7 \\
\hline \multicolumn{2}{|l|}{ Lower extremity DVC } \\
\hline Yes & 14 \\
\hline Right side & 9 \\
\hline Left side & 5 \\
\hline Mean time \pm SD (days) & $3.23 \pm 1.59$ \\
\hline No & 0 \\
\hline Intraoperative anticoagulation & 0 \\
\hline \multicolumn{2}{|l|}{ Postoperative anticoagulation } \\
\hline Yes & 7 \\
\hline LMWH & 0 \\
\hline Alprostadil & 7 \\
\hline No & 7 \\
\hline Mechanical prophylaxis & 0 \\
\hline $\begin{array}{l}\text { Time point of presentation of VTE } \\
\text { (Mean postoperative days) }\end{array}$ & $6.57 \pm 3.76$ \\
\hline \multicolumn{2}{|l|}{ Other complications } \\
\hline Pulmonary infection & 9 \\
\hline Pleural effusion & 2 \\
\hline Aspiration pneumonia & 1 \\
\hline
\end{tabular}


range from 200 to 1000) (Table 5). Lower extremity DVC was performed in all 14 patients via femoral vein puncture, 5 cases in left side and 9 cases in right side. Among the 8 patients of DVT, 5 cases occurred on the ipsilateral of DVC and initial symptom was the pain and swelling at the position of DVC. The other 3 cases occurred on the ipsilateral of flap and initial symptom was the pain and swelling of the lower extremity (Table $3)$. The mean time of DVC usage was 3.23 days $( \pm 1.59$; range from 0 to 6) (Table 5). DVC was usually removed within 5 days, and the rule was broken only in 1 patient whose DVC was removed in the 6th day. In particular, one patient was discovered swelling in the position of femoral vein puncture in the end of the surgery and a diagnosis of DVT was made. For this case, the time of DVC usage was recorded as 0 day (Table 3).

Postoperative prophylaxis was recorded. Anticoagulation was performed in 7 patients and alprostadil was used rather than LMWH (low molecular weight heparin) (Table 3). Mechanical prophylaxis, neither graduated elastic stocking (GES) nor intermittent pneumatic compression (IHC) was performed. The time point of presentation of VTE ranged from the end of the surgery to 13th day post operation, and the mean was 6.57 days $( \pm 3.76)$ post operation (Table 5). Most of the initial symptom of DVT was pain and swelling of lower extremity whereas decline of oxygen saturation (SPO2) and pressure of arterial oxygen $(\mathrm{PaO} 2)$ was the most common initial symptom of PE (Table 3 ). For the cases of PE, pulmonary artery trunk was embolized in one case (Fig. 1A), and inferior vena cava filter and urokinase thrombolysis was performed. For the cases whose pulmonary arteriole was embolized (Fig. 1B), pulmo- nary infection was always discovered; the decline of SPO2 was corrected when LMWH and anti-infection therapy were performed simultaneously. For the cases of DVT, immobilization and LMWH were required in every case; inferior vena cava filter was employed in 2 cases in case of deadly PE (Table 3).

\section{Discussion}

The pathophysiology of VTE was elucidated by Virchow more than 150 years ago and Virchow's triad, comprising three elements - venous stasis, endothelial injury, and hypercoagulability - is still used to explain its development (8). In a review, Anderson and Spencer (8) verified that active cancer, together with advanced age, prolonged immobilization, type of operation, serious injury, previous VTE, and congestive heart failure, are "convincingly demonstrated" independent risk factors. Obesity, use of nicotine, chemotherapy, red cell transfusion, or coexisting medical conditions, could further increase the risk.

The incidence of thromboembolic disease in general population is relatively low. Malignant diseases are considered a serious risk factor for the development of VTE (9). The incidence of VTE in head and neck cancer patients was reported as between $0.1 \%$ and $2 \%$. However, it should be kept in mind that the true rates could have been underestimated because of the limitations of these studies. First, not all patients with VTE become symptomatic. Second, the analysis relied, like all retrospective studies, on adequate record keeping. So far, rare had been reported in Chinese population on the topic of VTE, especially in oral and maxillofacial surgery.

In our study, several special characters had been re-

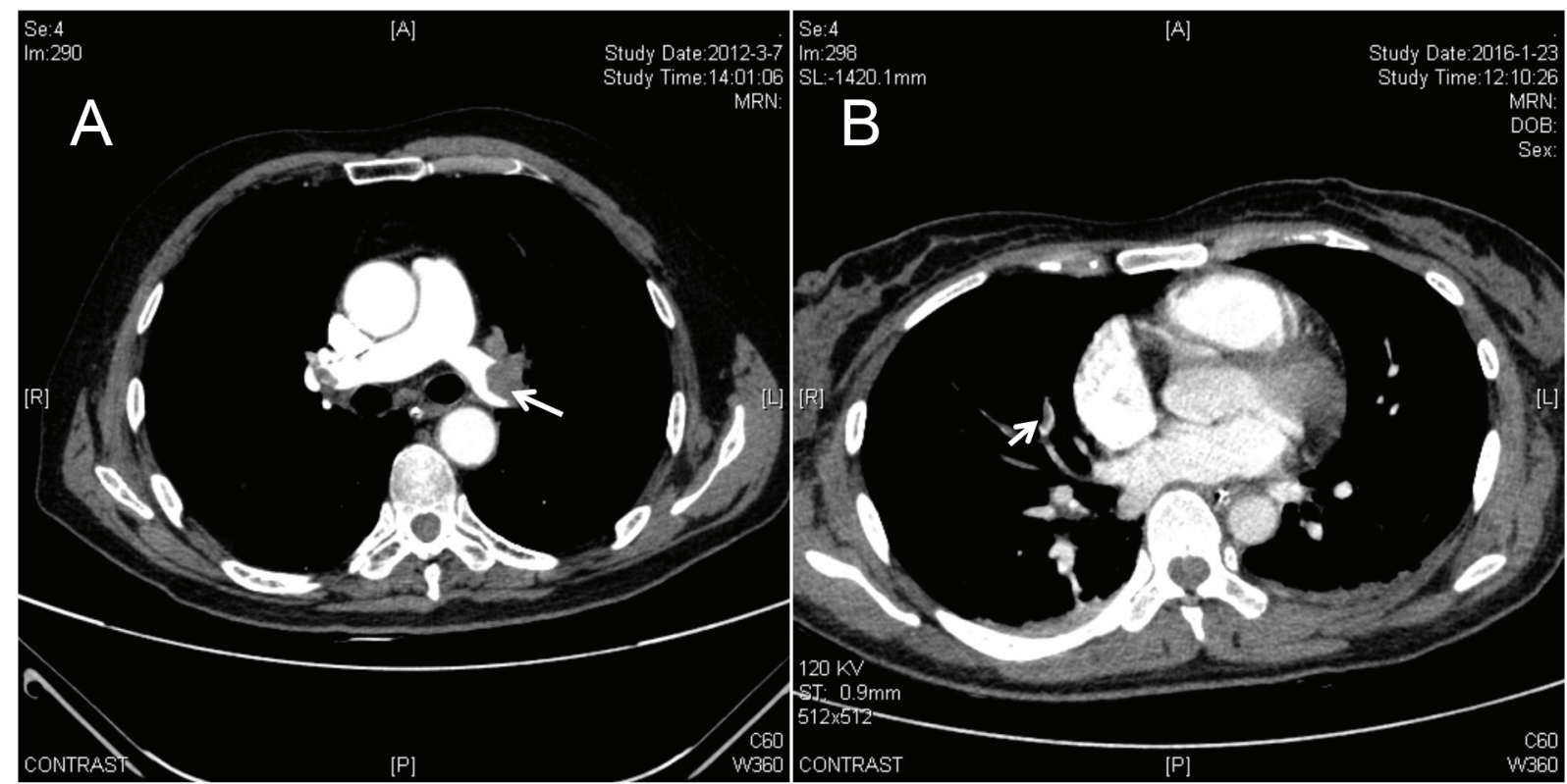

Fig. 1. PE diagnosed by CTA of pulmonary artery. (A) Pulmonary artery trunk was embolized. (B) Pulmonary arteriole was embolized. The arrows show the thrombus. 
vealed in oral and maxillofacial cancer patients and the perioperative treatment.

First, patients who suffered oral and maxillofacial cancer were usually elder. In our study of these 14 cases, 13 patients were over 45 years old, 9 patients over 60 and 6 patients over 70 . The mean age was 62.07 years (Tables 1,4). And age was found to be a risk factor in patients with cancer associated VTE in several studies. On the other hand, occurrence of systemic disorder, for example hypertension, diabetes and cerebral infraction, in elder patients was higher than younger patient, which make the risk of VTE higher.

Second, oral and maxillofacial cancer patients usually need a radical resection, and the simultaneous reconstruction is necessary for functional and aesthetical requirement. Flap transplantation for the reconstruction of recipient defect always prolonged the surgery procedure, otherwise, for the sake of adequate blood supply to the flap in head and neck region, and avoiding twist of vascular pedicel, patients with flap transplantation were required to lie on the back and immobilize at least for 3 days according to our department's standard of care. In spite of lower extremity massage, immobilization increased the risk of VTE.

In our study, reconstruction was performed in 12 patients of these cases including 10 vascularized free flaps and 2 pedicel flaps (Table 5). ALTF and fibula flap were now very popular for reconstruction of soft tissue and osseous tissue defect respectively. In our study, three cases of DVT occurred on the ipsilateral of flap elevation, including ALTF, fibula flap and DCIA. 4 in 6 cases of PE got a reconstruction with ALTF. During flap elevation, especially flaps involving lower extremity, GES and IHC were not convenient to use. Also, the transection and division make injury to lower extremity vessel, which was potential risk factor of DVT.

Third, DVC was applied universally during major surgery in our department. Among the 8 patients of DVT, 5 cases occurred on the ipsilateral of DVC and initial symptom was the pain and swelling at the puncture position (Table 3). The most favorite puncture position of DVC was right femoral vein because of increased potential risk of thrombosis in left femoral vein, which was oppressed by iliac artery anatomically. Also, the puncture position verified depending on the donor site of flaps. Anyway, lower extremity DVC has a high correlation with DVT according to our study. Although central venous access was recognized as a risk factor for VTE, rare had reported the correlation between DVT and lower extremity DVC as in our study.

Additionally, neck dissection was frequently necessary in head and neck cancer surgery because of high rate of lymph node metastasis. The division of jugular vein may result in endothelial injury, which was consistent with Virchow's triad. Further more, the upper respiratory tract was usually involved in head and neck cancer surgery. To alleviate swelling and get airway unobstructed as soon as possible, high-dose glucocorticoid, which was elucidated as a risk factor of VTE, was applied.

So far, more than 25 evidence-based guidelines on the prevention of VTE by the appropriate use of prophylaxis have been developed on the basis of results of clinical trials in different cohorts of at-risk patients since 1986. These include guidelines published by the American College of Chest Physicians (ACCP) (10-12), the ninth edition of which was published in 2012 and those issued by the American Association of Orthopedic Surgeons (AAOS) (13) in 2012, which offer substantial insight into the risk of VTE as well as appropriate prophylaxis measures in orthopedic patients. Unfortunately there was no guideline for oral and maxillofacial surgery specifically.

Understanding guidelines and recommendations from other specialties will help us to make more appropriate decision for our patients. The most widely used risk assessment tool was developed by Caprini (14). The Caprini risk assessment tool has been updated periodically since 30 years ago. According to this model, approximately 40 risk factors are listed, with weights of 1 to 5 points each. The total risk factor score is then used to group patients into 1 of 4 categories (low, moderate, high, and highest risk), each with a recommended prophylactic treatment. The Caprini risk assessment tool has been validated in retrospective studies for use in patients needing elective general surgery and modified for use in patients needing plastic surgery (15-18). We make a Caprini score for every case according to ACCP9 retrospectively, found that every patient got a very high Caprini score (score $\geq 9$ ) (Table 3) and fell into high-risk group which should be dealt with aggressive thromboprophylaxis. But in reality, only prophylactic alprostadil was used in 7 cases, no postoperative LMWH was applied prophylactically. The main concern was that routine prophylactic anticoagulation will increase the risk of postoperative hematoma, which can compromise flap viability or upper respiratory tract. Thus, currently few oral and maxillofacial surgeons routinely prescribe anticoagulation after resection and microvascular reconstruction. Meta-analysis has shown that pneumatic compression devices also decrease DVT in patients undergoing surgical procedures by over $60 \%$. But unfortunately it was not available in our department. GES was also not widespread generalized because of apathetic awareness of VTE.

\section{Conclusions}

In this study we aimed to identify potential risk factors for developing VTE for patients with head and neck cancer. We analyzed several characters of oral and maxillofacial surgery and suggested pay attention to lower extremity DVC which had a high correlation with DVT 
according to our data. And challenges to patient care in our department include lack of equipment like IHC, application of GES and et al.

\section{Reference}

1. Shinagare AB, Okajima Y, Oxnard GR, Dipiro PJ, Johnson BE, Hatabu $\mathrm{H}$, et al. Unsuspected pulmonary embolism in lung cancer patients: comparison of clinical characteristics and outcome with suspected pulmonary embolism. Lung Cancer. 2012;78:161-6.

2. Falanga A. The incidence and risk of venous thromboembolism associated with cancer and nonsurgical cancer treatment. Cancer Investig. 2009;27:105-15.

3. Moreano EH, Hutchison JL, McCulloch TM, Graham SM, Funk GF, Hoffman HT. Incidence of deep venous thrombosis and pulmonary embolism in otolaryngology-head and neck surgery. Otolaryngol Head Neck Surg. 1998;118:777-84.

4. Chen CM, Disa JJ, Cordeiro PG, Pusic AL, McCarthy CM, Mehrara BJ. The incidence of venous thromboembolism after oncologic head and neck reconstruction. Ann Plast Surg. 2008;60:476-9.

5. Innis WP, Anderson TD. Deep venous thrombosis and pulmonary embolism in otolaryngologic patients. Am J Otolaryngol. 2009;30:230-3.

6. Lee J, Alexander A, Higgins K, Geerts W. The Sunnybrook experience: review of deep vein thrombosis and pulmonary embolism in otolaryngology. J Otolaryngol Head Neck Surg. 2008;37:547-51.

7. Ali NS, Nawaz A, Junaid M, Kazi M, Akhtar S. Venous Thromboembolism-Incidence of Deep Venous Thrombosis and Pulmonary Embolism in Patients with Head and Neck Cancer: A Tertiary Care Experience in Pakistan. International Archives of Otorhinolaryngology. 2015;19:200-4.

8. Anderson FA Jr, Spencer FA. Risk factors for venous thromboembolism. Circulation. 2003;107:9-16.

9. Falck-Ytter Y, Francis CW, Johanson NA, Curley C, Dahl OE, Schulman S, et al. Prevention of VTE in orthopedic surgery patients: Antithrombotic Therapy and Prevention of Thrombosis, 9th ed: American College of Chest Physicians Evidence-Based Clinical Practice Guidelines. Chest. 2012;141(2 Suppl):e278S-325S

10. Gould MK, Garcia DA, Wren SM, Karanicolas PJ, Arcelus JI, Heit JA, et al. Prevention of VTE in nonorthopedic surgical patients: Antithrombotic Therapy and Prevention of Thrombosis, 9th ed: American College of Chest Physicians Evidence-Based Clinical Practice Guidelines. Chest. 2012;141(2 Suppl):e227S-77S.

11. Guyatt GH, Akl EA, Crowther M, Schünemann HJ, Gutterman DD, Zelman Lewis S, et al. Introduction to the ninth edition: Antithrombotic Therapy and Prevention of Thrombosis, 9th ed: American College of Chest Physicians Evidence-Based Clinical Practice Guidelines. Chest. 2012;141(2 Suppl):48S-52S.

12. Kahn SR, Lim W, Dunn AS, Cushman M, Dentali F, Akl EA, et al. Prevention of VTE in nonsurgical patients: Antithrombotic Therapy and Prevention of Thrombosis, 9th ed: American College of Chest Physicians Evidence-Based Clinical Practice Guidelines. Chest. 2012;141(2 Suppl):e195S-226S.

13. Jacobs JJ, Mont MA, Bozic KJ, Della Valle CJ, Goodman SB, Lewis CG, et al. American Academy of Orthopaedic Surgeons clinical practice guideline on: preventing venous thromboembolic disease in patients undergoing elective hip and knee arthroplasty. J Bone Joint Surg Am. 2012;94:746-7.

14. Caprini JA. Risk assessment as a guide for the prevention of the many faces of venous thromboembolism. Am J Surg. 2010;199:S310.

15. Collins R, Scrimgeour A, Yusuf S, Peto R. Reduction in fatal pulmonary embolism and venous thrombosis by perioperative administration of subcutaneous heparin. Overview of results of randomized trials in general, orthopedic, and urologic surgery. N Engl J Med. 1988;318:1162173.
16. Pannucci CJ, Dreszer G, Wachtman CF, Bailey SH, Portschy PR, Hamill JB, et al. Postoperative enoxaparin prevents symptomatic venous thromboembolism in high-risk plastic surgery patients. Plast Reconstr Surg. 2011;128:1093-103.

17. Pannucci CJ, Bailey SH, Dreszer G, Fisher Wachtman C, Zumsteg JW, Jaber RM, et al. Validation of the Caprini risk assessment model in plastic and reconstructive surgery patients. J Am Coll Surg. 2011;212:105-13.

18. Pannucci CJ, Barta RJ, Portschy PR, Dreszer G, Hoxworth RE, Kalliainen LK, et al. Assessment of postoperative venous thromboembolism risk in plastic surgery patients using the 2005 and 2010 Caprini Risk score. Plast Reconstr Surg. 2012;130:343-53.

\section{Acknowledgment}

This work was supported by the foundation of Shanghai Ninth People's Hospital (grant 2015-02).

Yang Wang and Jiannan Liu made equal contributions to this article (joint first authors).

\section{Conflict of Interest}

The authors have declared that no conflict of interest exist. 